\title{
ANALYSIS OF RAINFALL AND DROUGHT IN RAJASTHAN STATE, INDIA
}

\section{MUNDETIA N.* SHARMA D.}

Received: 28/02/2014

Accepted: 01/05/2014

Available online: 04/06/2014

\author{
Department of Environmental Science \\ Central University of Rajasthan, Rajasthan, India
}

\section{ABSTRACT}

Rainfall indices and Standardized Precipitation Index (SPI) were obtained for Rajasthan State characterized as the most sensitive and vulnerable state in India. Daily rainfall data of 35 years (19712005) for 31 well-spread stations were used to generate critical area maps. From the analysis of rainfall indices, it is observed that few stations situated in east and south-eastern side in the state have shown high negative change for annual and monthly rainfall but not such negative change is observed in the case of average number of wet days for the same stations. Similarly from SPI drought analysis both short term and long term, higher tendency of mild droughts is observed than moderate and severe droughts with a noticeable increase in occurrence of severe droughts on longer time scales. The study describes importance of SPI and rainfall indices in understanding the climate change impacts and droughts to provide better assessment and management aspects for the society.

Keywords: Standardized Precipitation Index (SPI), drought indices, frequencies, average rainfall, Rajasthan.

\section{Introduction}

Climate change is one of the key global challenges in the present era. It refers to a statistically significant variation in either the mean state of the climate or in its variability, persisting for an extended period typically decades or long (World Meteorological Department). Mainly natural processes and persistent anthropogenic influences are responsible for it, altering the composition of the global atmosphere and natural climatic system. According to Intergovernmental Panel on Climate Change Fourth Assessment Report the world indeed has become more drought prone with higher frequencies of extreme events (IPCC REPORT, 2007) some clear instances around the world can be noticed, like changing trends of monsoonal rainfall over India due to climate change (Naidu et al., 2009) increase in drought events in UK (Arnell, 2007), in Korean peninsula (Kyoung et al., 2011), in Iran (Sayari et al., 2013), and over Indian subcontinent (Sivakumar and Stefanski, 2011) describing the impacts of climate change. In India, 80\% of annual rainfall comes from southwest monsoon, and very important for the whole country, especially for the low rainfall belts like Rajasthan state. Any kind of deficiency in monsoon, mostly because of climate change causes higher frequencies of droughts in these areas as high as once in every four years (Gupta et al., 2011). Out of 13 states repeatedly declared as drought-prone, Rajasthan is the most critical state in the country with highest probabilities of drought occurrence and rainfall deficiencies. Several records shows that about 48 drought years have been reported of varied intensity since 1901 in last 102 years and only 9 years out of them were totally free from drought (Rathore, 2005). Limited water resources, erratic rainfall, and repetitive droughts lead to poor agricultural and economic condition in the state. So there is a need to adopt a proactive approach by strengthening the scientific advancement in 
understanding drought using different indices and identify the districts which are more severe to drought.

Drought can be referred as a normal recurring feature of earth's climate, it has a peculiar slow onset and disastrous, long lasting impacts; it affects more people than any other form of natural disaster. It is characterized in terms of spatial extension, intensity and duration (Drought Manual; Govt. of India, 2009).Generally rainfall deficiencies over a long time period leads to severe droughts events (Wilhite \& Knutson, 2008). Mainly four types of droughts are mostly observed, meteorological (lack of precipitation), agricultural (lack of root zone soil moisture), hydrological (drying of surface water storage), socio- economic drought (lack of water supply for socio-economic purpose) and these drought types are generally interlinked with each other (Sigdel and Ikeda, 2010).There are several drought indices available nowadays and ,SPI is one of the most widely used and commonly accepted drought index. It is recommend for agricultural and hydrological drought analysis by WMO (World Meteorological Department), because it is very simple, spatially consistent, probabilistic in nature and peculiar with the ability to represent droughts on both spatial and temporal scales, so it provides better results. Multi-time scale results such as $3,6,12,24$ months from SPI represents impacts of drought on different water availabilities like for soil moisture, water reserves, steam water and ground water etc (Guttman, 1998). Several examples of its significant use at different regions like, Nepal (Sigdel and Ikeda, 2010), Turkey (Sirdas and Sen, 2001; Sönmez et al., 2005) zimbabwe (Manatsa et al., 2010), Greece (Livada and Assimakopoulos, 2006; Karavitis et al., 2011), Iran (Sayari et al., 2013) also in India, Gujarat (Patel et al., 2007) Guwahati situated in Assam (Jhajharia et al., 2007), and at Aravali terrain Rajasthan (Bhuiyan et al., 2006) can be observed. There is also need to focus on water management aspects to conserve and use water in dry spells and drought situation (Sharma et al., 2010)

The present study is based on analysis of rainfall and drought events, with respect to the climate change. Negative or positive changes in rainfall indices were observed along with spatio temporal analysis of droughts using short term (3-6 months) and long term (12-24 months) SPI methods to obtain GIS based critical area maps, for better understanding of climate change impacts.

\section{Study area}

Rajasthan state is situated between $23^{\circ} 30^{\prime}-30^{\circ} 11^{\prime} \mathrm{N}$ and $69^{\circ} 29^{\prime}-78^{\circ} 17^{\prime} \mathrm{E}$ at the northwestern region of India, covering a widespread area of $3,42,239 \mathrm{~km}^{2}$ (10.4\% of the country).

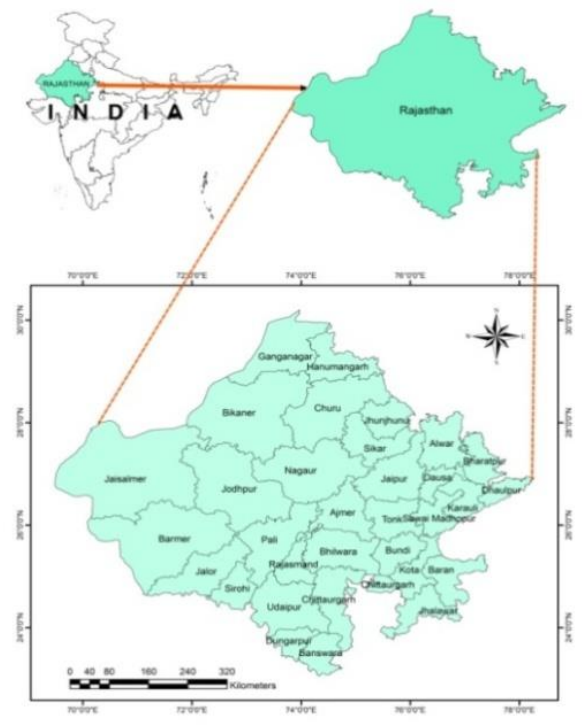

Map showing District name and location of IMD stations

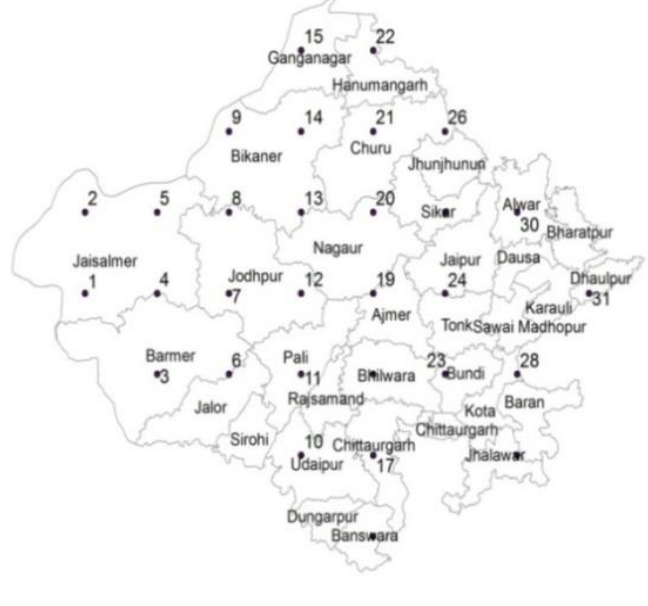

Figure 1. Location map of the selected sites in Rajasthan 
As per details from Census 2011, it has population of about 68 million and $75 \%$ of this population resides in rural areas and directly dependent upon rainfall availabilities for agriculture and other use. Four regions can be clearly demarcated in the state, desert in west with barren hills, rocky/sandy plains in north east, the Aravali hills in the centre, extending from north to south, and south eastern plateau. Climate varies from arid in west and semi arid to sub humid in southeast. Low and erratic rainfall in the state characterizes it as one of the driest state in India, it receives about $574 \mathrm{~mm}$ average annual rainfall which deviates from as low as $100 \mathrm{~mm}$ in Jaisalmer (Lowest in the state) to $550 \mathrm{~mm}$ in Ajmer and highest $(1638 \mathrm{~mm}$ ) in Mount Abu (Sirohi district) situated on southeast region of the state. The whole state was considered as the study area taking 31 stations as data collection points, well spread over the state, covering all the districts.

\section{Methodology}

Daily rainfall data from Indian Meteorological Department for a period of 35 years (1971-2005) of 31 stations were collected and processed on Excel sheets according to the requirements to obtain critical area maps using ArcGIS 10.1 software.

\subsection{Rainfall indices and mapping}

Several rainfall indices were generated in the study, to estimate the change occurred in rainfall patterns between the two periods of 17 years (1971-88 and 1989 -05). Rainfall indices generated are-

- Change in average annual rainfall

- Change in average number of wet days

- Month wise change in monsoonal rainfall

To obtain these rainfall indices firstly the daily rainfall data set of the 31 stations were converted into monthly and annually data. Then the whole dataset of all the stations for 35 years (1971-2005) were divided into two periods of 17 years (1971-88 and 1989-05) to measure a change occurred in the indices between the two periods. Average annual rainfall, average numbers of wet days ( $>0 \mathrm{~mm}$ rainfall) and monsoonal month wise average rainfalls were calculated for each period and for each station then change occurred between the periods were calculated. These values then further applied in ArcGIS software 10.1 to generate critical area maps highlighting stations showing positive and negative change. Higher negative change is highlighted with red color symbols and positive change from blue color symbols in the rainfall indices maps.

\subsection{SPI calculation and mapping}

Standardized precipitation index (SPI) is the simplest drought index based on precipitation data, developed in 1993 by Thomson b. Macke (Mckee et al.,1993) to measure precipitation deficit for multiple time scale. According to normal distribution, it can be calculated by taking the difference of the precipitation from the mean for particular time scale then dividing by the standard deviation,

$$
\mathrm{SPI}=(\mathrm{X}-\mathrm{Xm}) / \sigma
$$

Where $X$ is precipitation for the station, $X m$ is mean precipitation and $\sigma$ is standardized deviation. The long-term record is fitted to a probability distribution, which is then transformed into a normal distribution so that the mean SPI for the location and desired period is zero (Katsabani and Mavrakis, 2011). Drought event occurs when SPI is continuously negative and reaches an intensity of -1 or less and ends when the SPI becomes positive. In present study SPI was calculated using software SPI calculator, SPI_SL_6exe, implemented as a unix-style filter, a program to calculate SPI values, it reads from standard input (stdin) and write to standard output (stdout). Daily rainfall data for each station were converted into monthly data and changed into a standard three column format (year, month, precipitation,) suitable for SPI calculator as an input file, then SPI for 3, 6, 12, 24 months were calculated. Obtained SPI values then further classified according to given Table 1 then from the droughts classes, critical area maps were generated using ArcGIS software.10.1. 
Table 1. SPI drought classes

\begin{tabular}{ccc}
\hline S. No & Criteria of SPI values & Type of drought \\
\hline 1. & 0.00 to -0.99 & Mild drought \\
\hline 2 & -1.0 to -1.49 & Moderate drought \\
\hline 3. & -1.5 to -1.99 & Severe drought \\
\hline 4. & -2 and less & Extreme drought \\
\hline 5. & More than 0 & Above normal drought \\
\hline
\end{tabular}

\section{Results and discussion}

Eighteen critical area maps were generated in the study in which 6 from rainfall indices and 12 from SPI drought analysis using ArcGIS software 10.1, highlighting critical stations with red color symbols in all maps.

\subsection{Rainfall indices}

Different rainfall indices were generated calculating the change occurred between the two periods of 17 years (1989- 05 and 1971-1988). Six maps were generated describing change in average annual rainfall, average number of wet days and monsoonal month wise change occurred in all stations, highlighting the more sensitive and critical stations with red color symbols in which higher values of negative change is observed.

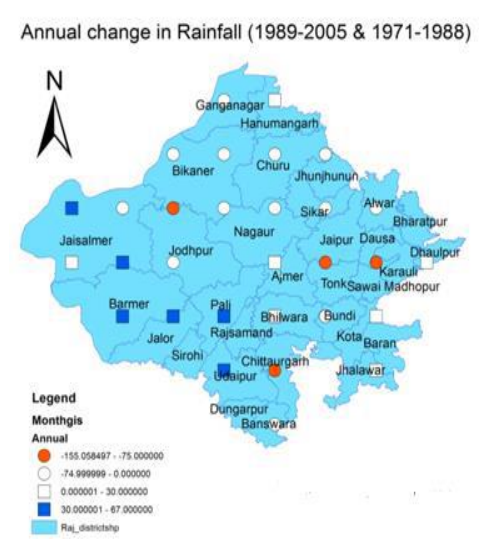

(a)
Change in number of wet days (1989-2005 \& 1971-1988

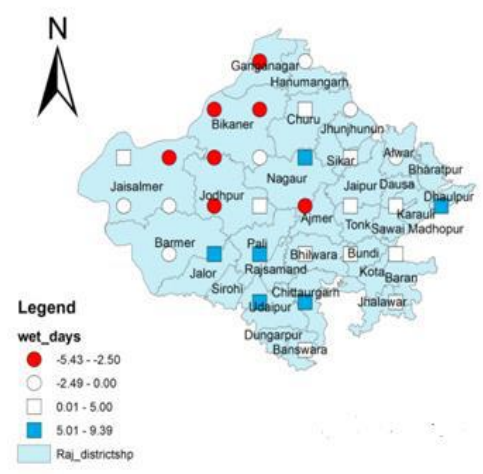

(b)

Figure 2. Change in annual rainfall and number of wet days in Rajasthan

All the stations have shown both kinds of change, negative or positive depicting the climate change impacts on rainfall indices. Higher negative change is mainly observed in few stations from eastern and southeastern parts of the state in the case of average annual and monthly monsoonal rainfall whereas no such negative change is observed in eastern side stations for average number of wet days though observed in few western stations. All the observations are summarized in the Table 2.

Mainly east and south east part of the state is identified as more vulnerable to climate change from the above results. Higher negative change is observed despite the fact that these areas receive high rainfall than other parts of the state. The similar type of results were obtained by Rathore, (2005) using 102 years rainfall data and concluded that south eastern, eastern part of the state have high rainfall variability and are more vulnerable to drought conditions. Thus a rainfall index significantly describes 
about climate change impacts and very important tool to estimate the change and related consequences over any region.

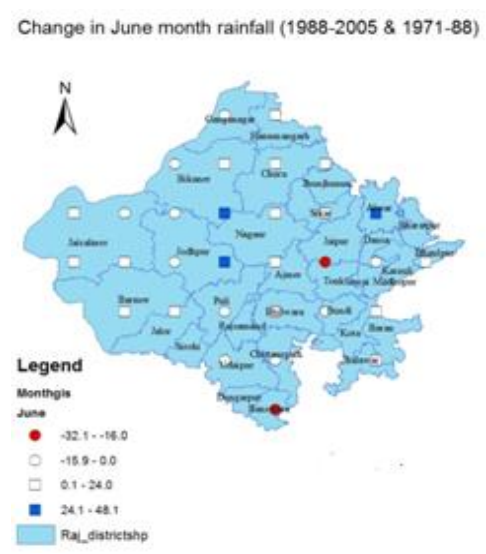

(c)

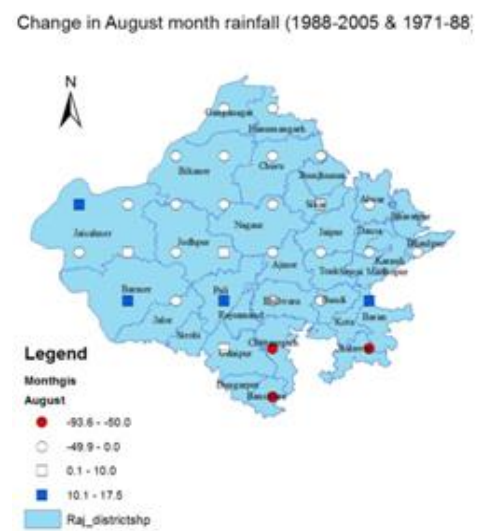

(e)

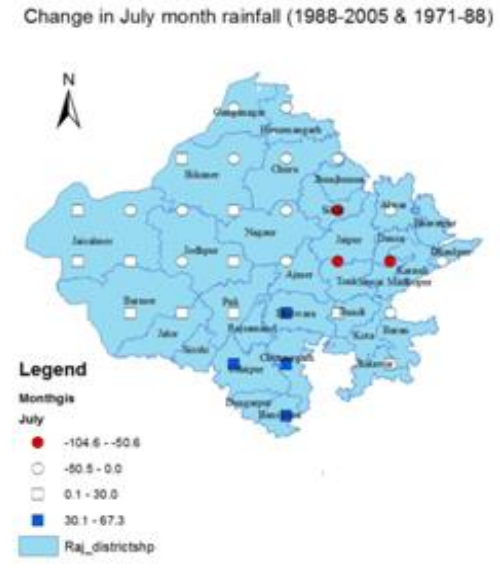

(d)

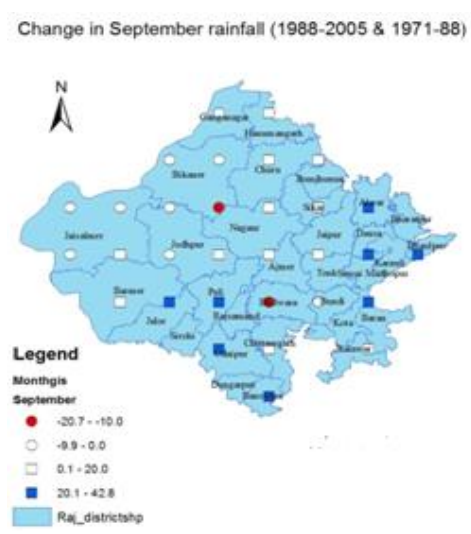

(f)

Figure 3. Maps showing month wise change in monsoonal rainfall

Table 2. List of districts showing highest negative change between two time periods

\begin{tabular}{|c|c|c|}
\hline Rainfall indices generated & $\begin{array}{l}\text { Districts showing } \\
\text { Highest range of positive change }\end{array}$ & $\begin{array}{l}\text { Districts showing } \\
\text { Highest range of negative change }\end{array}$ \\
\hline Annual rainfall & $\begin{array}{c}\text { Jaisalmer, Barmer, Jalore, } \\
\text { Udaipur, Pali }\end{array}$ & $\begin{array}{l}\text { Bikaner,Swaimadhopur } \\
\text { Jaipur,Chittorgarh }\end{array}$ \\
\hline $\begin{array}{c}\text { Change in number of wet } \\
\text { days }\end{array}$ & $\begin{array}{l}\text { Pali,Nagour,Udaipur,Jalore } \\
\text { Chittorgarh,Dholpur, Udaipur }\end{array}$ & $\begin{array}{c}\text { Ganganager,Jodhpur, } \\
\text { Bikaner, Ajmer, Jaisalmer }\end{array}$ \\
\hline $\begin{array}{l}\text { Change in June month } \\
\text { rainfall }\end{array}$ & $\begin{array}{c}\text { Bikaner ,Jodhpur } \\
\text { Alwer }\end{array}$ & $\begin{array}{c}\text { Jaipur, } \\
\text { Banswara }\end{array}$ \\
\hline $\begin{array}{l}\text { Change in July month } \\
\text { rainfall }\end{array}$ & $\begin{array}{l}\text { Bhilwara, Udaipur, } \\
\text { Chittorgarh, Banswara }\end{array}$ & $\begin{array}{l}\text { Sikar, Jaipur, } \\
\text { Swaimadhopur }\end{array}$ \\
\hline $\begin{array}{l}\text { Change in August month } \\
\text { rainfall }\end{array}$ & $\begin{array}{l}\text { Jaisalmer, Barmer } \\
\text { Pali, Baran }\end{array}$ & $\begin{array}{c}\text { Chittorgarh, Jahalawar } \\
\text { Banswara }\end{array}$ \\
\hline $\begin{array}{l}\text { Change in September } \\
\text { month rainfall }\end{array}$ & $\begin{array}{c}\text { Jolore ,Pali, Banswara } \\
\text { Udaipur, Baran, Alwer } \\
\text { Dausa ,Dholpur }\end{array}$ & Bhilwara, Bikaner \\
\hline
\end{tabular}




\subsection{SPI analysis}

Twelve maps were obtained from SPI analysis of 3, 6, 12, 24 months, highlighting stations with higher percentage of drought occurrence in given period of 35 years (1971-05). SPI results are categorized as short term and long term analysis in order to provide comparative analysis and suggesting short and long term measures accordingly.

\subsubsection{Short term analysis (3 months and 6 months)}

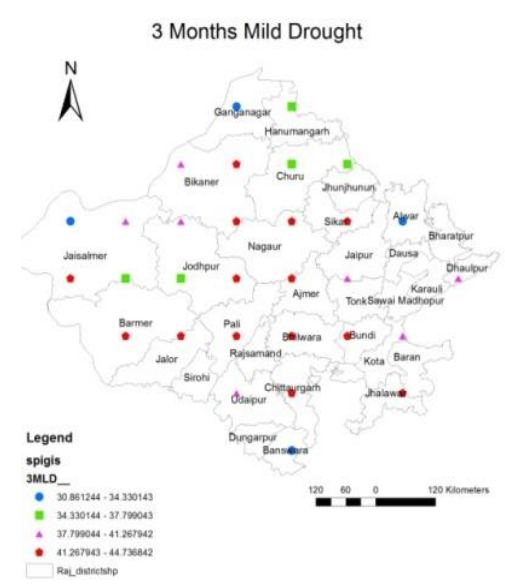

(a)

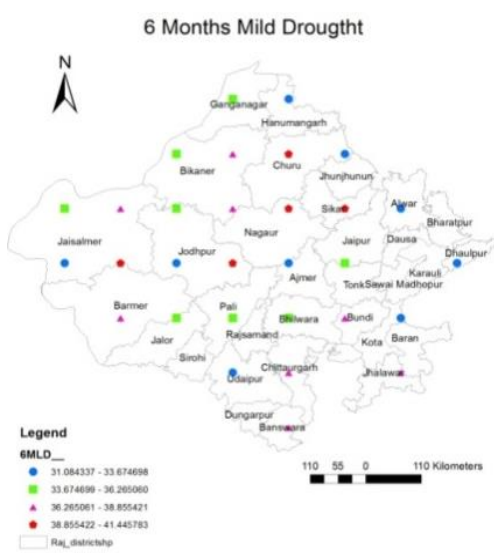

(d)

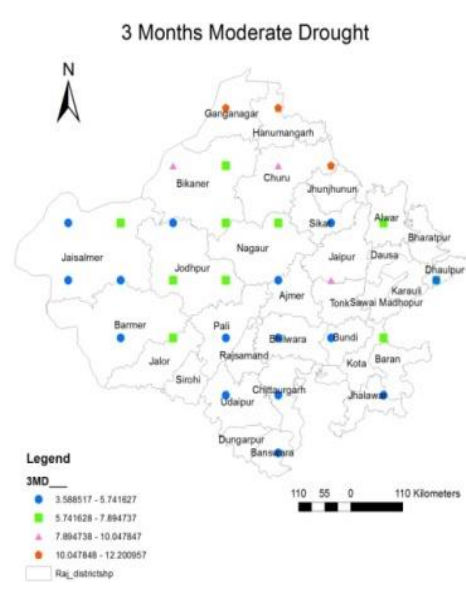

(b)

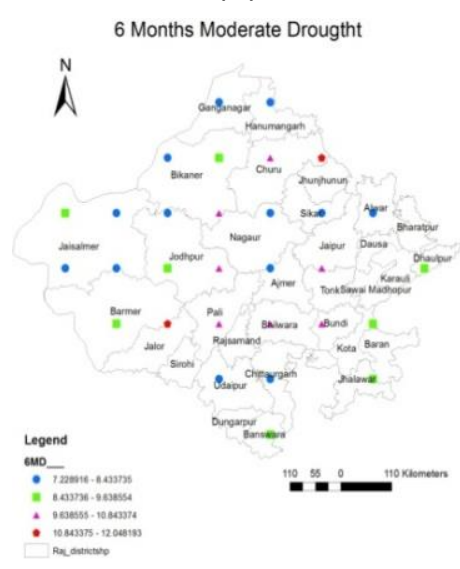

(e)

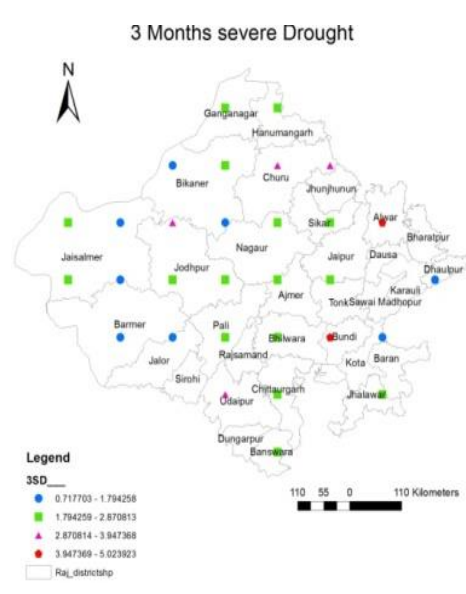

(c)

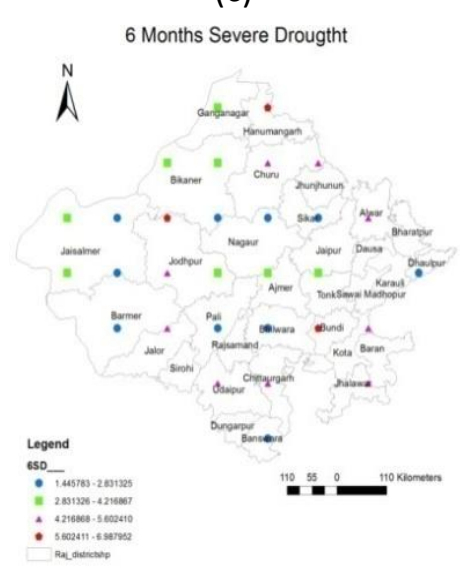

(f)

Figure 4. Short term (3, 6 months) SPI analysis, for mild, moderate and severe drought

Results from 3 months and 6 months SPI are categorized as short term analysis (Fig. 4) because it provides estimation of drought impacts on short time scale, mainly drought frequencies for mild, moderate and severe types of drought were obtained and stations with higher drought frequencies were highlighted with red color symbols in the maps. The 3 month SPI is useful for short and medium term moisture conditions for agriculture, and provides a seasonal precipitation estimation, which represents deviation in precipitation totals. For example, the 3-month SPI at the end of February compares the December-January February precipitation total in that particular year with the December January February precipitation totals of all the years. The same is true for 6 months totals and calculated in similar manner. It can be very effective in showing the precipitation over distinct seasons and information from a 6-month SPI may also begin to be associated with anomalous stream flows to be associated with anomalous stream flows and reservoir levels.

Short term analysis shows that there is a higher probability of mild droughts than moderate or severe droughts in majority of the districts situated in central part of the state, in both 3 and 6 months SPI. There is a noticeable change in frequency percentages, it decrease for mild droughts and increase for 
severe droughts along the increase in the time scale. It can be observed from Table 3, given below comparing frequency percentage for mild and severe drought in 3 and 6 months SPI. By identifying the critical stations, a short term measures can be suggested for those areas to fulfill the agricultural requirements, attaining optimum soil moisture and reducing agricultural drought vulnerabilities. It is good to take proper measures early in response to mild drought which may turn into severe droughts on longer time scales.

Table 3. Results for short term drought analysis

\begin{tabular}{|c|c|c|c|c|c|}
\hline $\begin{array}{l}\text { Types of } \\
\text { droughts }\end{array}$ & $\begin{array}{c}\text { Range of SPI } \\
\text { values }\end{array}$ & $\begin{array}{l}3 \text { month } \\
\text { SPI } \\
\text { Frequency } \\
\text { percentage }\end{array}$ & $\begin{array}{l}6 \text { month } \\
\text { SPI } \\
\text { Frequency } \\
\text { percentage }\end{array}$ & $\begin{array}{c}\text { Critical districts in } 3 \\
\text { months SPI }\end{array}$ & $\begin{array}{l}\text { Critical districts } \\
\text { in } 6 \text { monthsSPI }\end{array}$ \\
\hline $\begin{array}{l}\text { Mild } \\
\text { drought }\end{array}$ & 0.00 to -0.99 & $41.3-44.7$ & $38.8-41.4$ & $\begin{array}{c}\text { Bikaner, Nagaur, } \\
\text { Sikar, Jodhpur, } \\
\text { Ajmer,Barmer, } \\
\text { Jaisaler,Pali, } \\
\text { Jalore,Bhilwara, } \\
\text { Bundi, Jhalawar, } \\
\text { Chittaurgarh }\end{array}$ & $\begin{array}{c}\text { Churu, Nagaur, } \\
\text { Sikar, Jodhpur, } \\
\text { Jaisalmer, } \\
\text { Barmer }\end{array}$ \\
\hline $\begin{array}{l}\text { Moderate } \\
\text { drought }\end{array}$ & -1.0 to -1.49 & $10-12.2$ & $10.8-12$ & $\begin{array}{c}\text { Ganganagar, } \\
\text { Hanumangarh, } \\
\text { Churu }\end{array}$ & Churu, Jalore \\
\hline $\begin{array}{l}\text { Severe } \\
\text { drought }\end{array}$ & -1.5 to -1.99 & $3.9-5.0$ & $5.6-6.9$ & Alwar, Bundi & $\begin{array}{l}\text { Hanumangarh, } \\
\text { Jodhpur, Bundi }\end{array}$ \\
\hline
\end{tabular}

\subsubsection{Long term analysis (12 months and 24 months)}

Results obtained from 12 and 24 months SPI are categorized as long term analysis, depicting drought frequencies, for mild, moderate and severe types of droughts by all the stations, highlighting the critical ones from red color symbols.

Table 4. Results for long term drought analysis

\begin{tabular}{|c|c|c|c|c|c|}
\hline $\begin{array}{l}\text { Types of } \\
\text { droughts }\end{array}$ & $\begin{array}{l}\text { Range of SPI } \\
\text { values }\end{array}$ & $\begin{array}{l}12 \text { month } \\
\text { SPI } \\
\text { Frequency } \\
\text { percentage }\end{array}$ & $\begin{array}{l}24 \text { month } \\
\text { SPI } \\
\text { Frequency } \\
\text { percentage }\end{array}$ & $\begin{array}{l}\text { Critical districts } \\
\text { in } 12 \text { months SPI }\end{array}$ & $\begin{array}{l}\text { Critical districts } \\
\text { in } 24 \text { months SPI }\end{array}$ \\
\hline $\begin{array}{l}\text { Mild } \\
\text { drought }\end{array}$ & 0.00 to -0.99 & $37.1-41$ & 44.7- 52.8 & $\begin{array}{c}\text { Ganganagar,Jaisalmer } \\
\text { Hanumangarh, } \\
\text { Bikaner,Nagaur,Sikar } \\
\text { Jaipur,Tonk,Bhilwara, } \\
\text { Jaisalmer,Jodhpur, } \\
\text { Barmer, Jalore, } \\
\text { Chittaurgarh, } \\
\text { Jhalawar }\end{array}$ & $\begin{array}{c}\text { Hanumangarh, } \\
\text { Churu,Nagaur, } \\
\text { Jaisalmer }\end{array}$ \\
\hline $\begin{array}{c}\text { Moderate } \\
\text { drought }\end{array}$ & -1.0 to -1.49 & $11.3-13.9$ & 13.09- 16.6 & $\begin{array}{c}\text { Bikaner,Churu, } \\
\text { Jodhpur,Bundi } \\
\text { Banswara }\end{array}$ & $\begin{array}{l}\text { Bikaner,Churu, } \\
\text { Jodhpur,Jaisalmer }\end{array}$ \\
\hline $\begin{array}{l}\text { Severe } \\
\text { drought }\end{array}$ & -1.5 to -1.99 & $8.5-10.7$ & $7.24-9.5$ & Jodhpur & Jodhpur,Barmer \\
\hline
\end{tabular}


Long term SPI describes the long time impacts of droughts on stream flow, reservoir storage and ground water level, thus ultimately it is related to hydrological droughts. Higher percentages of occurrence are observed for mild droughts than moderate or severe droughts covering most of the districts in the state. Whereas some stations situated in northwestern part of the state have shown higher frequencies for moderate and severe droughts. An increase in frequency percentages can be noticed in long term analysis, as shown in table 4 comparing different drought types and their frequency percentages for 12 and 24 months SPI. It is observed that there is a high probability of hydrological drought and depletion of ground water, stream flow in the critical areas. Thus; there is a prior need to adopt water conservation and management practices in those areas.

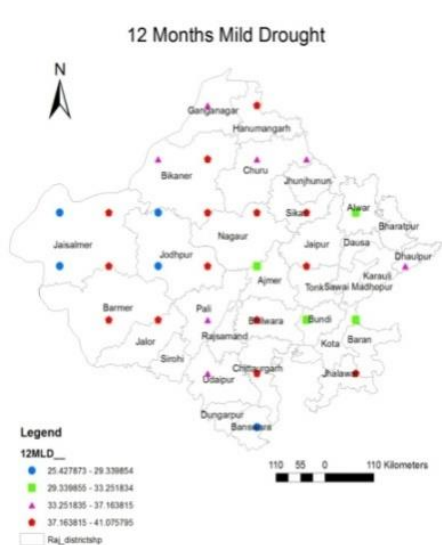

(a)

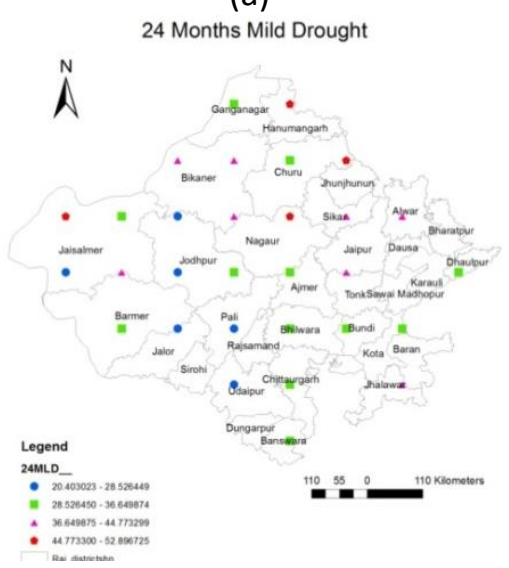

(d)

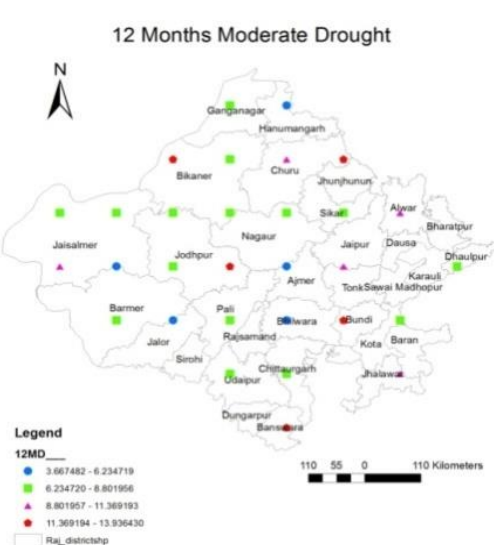

(b)

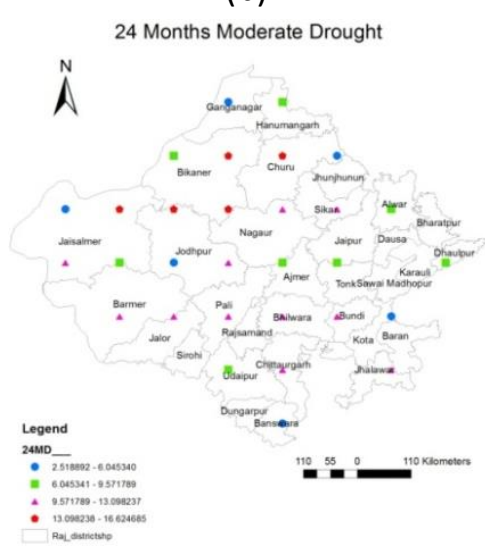

(e)

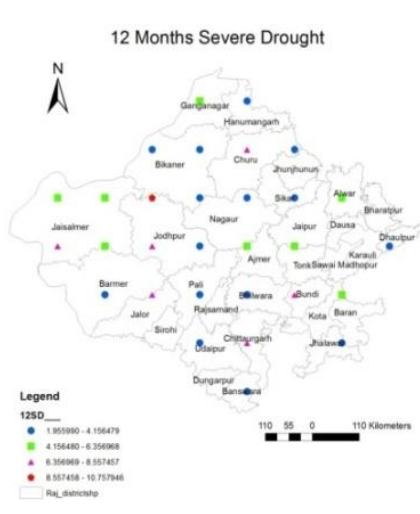

(c)

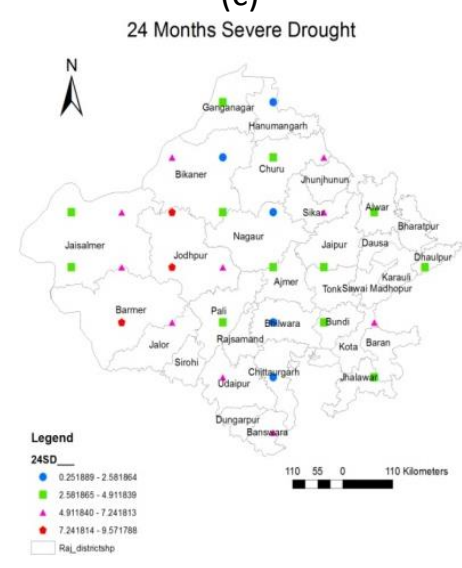

(f)

Figure 5. Long-term (3, 6 months) SPI analysis, for mild, moderate, and severe droughts

\section{Conclusion}

The study provides a comprehensive knowledge of change in rainfall indices and spatio- temporal extents of droughts due to climate change in Rajasthan. High negative change in rainfall indices have obtained for the eastern and southeastern parts of the state despite of having higher long time averages than other parts in the state. Similarly SPI drought index depicts that droughts in the state varies spatially and temporally from mild to severe, for all districts. Study shows higher percentage of occurrence of mild drought in the state covering large area, whereas severe drought frequency increases on long time scale. Short term analysis shows the loss of soil moisture and agricultural droughts and it requires short term measures like good irrigation system, and crop rotation for the critical areas.Similarly in long term analysis shows the impacts of droughts on stream flow and other surface water resources so proper conservation and management system and recharge capacities should be develop. The whole state is at the high risk, due to climate change and its impacts cannot be 
avoided completely but with the assessment of different indices and using advance tools, better understanding and better response can be generated to mitigate the impacts.

\section{ACKNOWLEDGEMENTS}

The authors express their sincere gratitude to India Meteorological Department (Pune) for providing rainfall data set and lat long information for the stations and National Drought Mitigation Center (University of NebraskaLincoln) for providing SPI SL 6.exe. We are also thankful the editors and anonymous referees for their valuable suggestions and constructive comments for improving the present paper.

\section{REFERENCES}

Arnell N.W. (2007), Climate change and drought, Options Méditerranéennes series A, 80, 13-20.

Bhuiyan C., Singh R.P. and Kogan F.N.(2006), Monitoring drought dynamics in the Aravalli region (India) using different indices based on ground and remote sensing data, International Journal of Applied Earth Observation and Geoinformation, 8, 289-302.

Climate Change 2007, Synthesis Report, An Assessment of the Intergovernmental Panel on Climate Change., IPCC XXVII (Valencia, Spain, 12-17 November 2007), Forth Assessment Report.

Gupta A.K., Tyagi P. and Sehgal V.K. (2011), Drought disaster challenges and mitigation in India : strategic appraisal, Current Science, 100(12), 1795-1806.

Guttman N.B. (1998), Comparing the Palmer drought index and standardized precipitation index, Journal of the American Water Resources Association, 34(1).

Jhajharia D., Shrivastava S.K., Tulla P.S. and Rituraj (2007), Rainfall Analysis for drought proneness at Guwahati, Indian J. Soil Cons., 35(2), 163-165.

Karavitis C.A., Alexandris S., Tsesmelis D.E. and Athanasopoulos G. (2011), Application of the Standardized Precipitation Index (SPI) in Greece, Water, 3,787-805.

Katsabani K. and Mavrakis A. (2011), Spatial and temporal evolution of drought episodes in Greece, Proceedings of the 12th International Conference on Environmental Science and Technology Rhodes, Greece, 8 - 10 September 2011 (pp. 8-10).

Kyoung M., Kwak J., Kim D., Kim H. and Singh V.P. (2011). Drought Analysis Based on SPI and SAD Curve for the Korean Peninsula Considering Climate Change, Climate Change - Geophysical Foundations and Ecological Effects, Dr Juan Blanco (Ed.), ISBN: 978-953-307-419-1, InTech, Available from: http://www.intechopen.com/books/climate-change-geophysical-foundations-and-ecological-effects/droughtanalysis-based-on-spi-and-sad-curve-for-the-korean-peninsula-considering-climate-change.

Livada I. and Assimakopoulos V.D.(2006), Spatial and temporal analysis of drought in greece using the Standardized Precipitation Index (SPI), Theoretical and Applied Climatology, 89(3-4), 143-153.

Manatsa D., Mukwada G., Siziba E. and Chinyanganya T. (2010), Analysis of multidimensional aspects of agricultural droughts in Zimbabwe using the Standardized Precipitation Index (SPI), Theoretical and Applied Climatology, 102(3-4), 287-305.

Manual for drought management, National Institute of Disaster Management (NIDM), Department of Agriculture, Government of India, New Delhi. (2009).(pp. 1-102).

Mckee T.B., Doesken N.J. and Kleist J. (1993), The relationship of drought frequency and duration to time scales, Eighth Conference on Applied Climatology, 17-22 January 1993, Anaheim, California.

Naidu C.V., Durgalakshmi K., Muni Krishna K., Ramalingeswara Rao S., Satyanarayana G.C., Lakshminarayana P. and Malleswara Rao L. (2009), Is summer monsoon rainfall decreasing over India in the global warming era?, Journal of Geophysical Research, 114(D24), D24108.

National Drought Mitigation Center University of Nebraska-Lincoln drought.unl.edu/MonitoringTools/DownloadableSPIProgram.aspx

Patel N.R., Chopra P. and Dadhwal V.K. (2007), Analyzing spatial patterns of meteorological drought using standardized precipitation index, Meteorological Applications, 14(4), 329-336.

Rathore M.S. (2005), State level analysis of drought policies and impacts in Rajasthan, India, International Water Management Institute ,Working paper 93 : Drought Series Paper No. 6, Colombo, Sri Lanka. 
Sayari N., Bannayan M., Alizadeh A. and Farid A. (2013), Using drought indices to assess climate change impacts on drought conditions in the northeast of Iran (case study: Kashafrood basin), Meteorological Applications, 20(1), 115-127.

Sharma D., Babel M.S. and Kumar V. (2010), An Approach for Efficient Rainwater Management for Agriculture in Arid Region of Rajasthan, India, International Journal of Water Resources and Environmental Management, Serial Publication, 1, 39-52.

Sigdel M. and Ikeda M. (2010), Spatial and Temporal Analysis of Drought in Nepal using Standardized Precipitation Index and its Relationship with Climate Indices, Journal of Hydrology and Meteorology, 7(1), 59-74.

Sirdas S. and Sen Z., Integrated water resources management. Selected papers from an International Symposium on Integrated Water Resources Management, University of California, Davis, California, USA, April 20002001 pp. 291-296, IAHS Publication No. 272.

Sivakumar M.V.K. and Stefanski R. (2011), Climate Change and Food Security in South Asia. (R. Lal, M. V. K. Sivakumar, S. M. A. Faiz, A. H. M. Mustafizur Rahman, \& K. R. Islam, Eds.). Dordrecht: Springer Netherlands, ISBN:10.1007/978-90-481-9516-9.

Sönmez F.K., Kömüscü A.Ü., Erkan A. and Turgu E. (2005), An Analysis of Spatial and Temporal Dimension of Drought Vulnerability in Turkey Using the Standardized Precipitation Index, Natural Hazards, 35(2), $243-264$.

Wilhite D. and Knutson C. (2008), Drought management planning: Conditions for success, Options Méditerranéennes Series A, 80, 141-148.

World Meteorological Department;http: //www.wmo.int/pages/prog/wcp/ccl/faqs.html, last visited 3 feb 2014. 